\section{IJ§ER}

ISSN: 2149-5939
International Journal of Social Sciences and Education Research

Online, http://dergipark.gov.tr/ijsser

Volume: 4(2), 2018

\title{
The effect of customer relationship tactics toward customer loyalty in banking industry
}

\author{
Masrul Hayati Kamarulzaman ${ }^{1}, \quad$ Nurain Farahana Zainal Abidin ${ }^{2}, \quad$ Siti Nur Shahira Dahari ${ }^{3}$ \\ Received Date: 01 / 04 / 2018 \\ Accepted Date: 30 / 06 / 2018
}

\begin{abstract}
The purpose of this study is to examine the effects of how Customer Relationship Marketing Tactics (CRMTs) on customer loyalty in banking industry specifically the credit card users. Through data from credit card users of $M B B$ and CIMB, we discuss five elements of CRMTs which are direct mail, preferential treatment, interpersonal communication, tangible rewards and membership and their influence on credit card users' loyalty towards their main banks. The credit card industry in Malaysia has been shrinking since the intervention from Bank Negara Malaysia in 2009 which has led to greater competition among credit card issuers. One reason being, customers nowadays are not loyal to their providers as they tend to switch to other substitute services and to other banks. Therefore, to retain the customers, successful Relationship Marketing can be achieved by considering customers' attitude towards their service provider through CRMTs. This will encourage both parties to appreciate the involvement in the relationship. This research findings' support that all CRMTs have significant relationship with credit card users' loyalty. Through multiple regressions, it was found that the most significance in contributing to credit card users' loyalty was membership and direct mail. Therefore, the outcome of this research provides a guide for $M B B$ and CIMB and also other financial institutions in charting strategic actions to maintain and retain their existing customers.
\end{abstract}

Keywords: Customer Relationship Marketing Tactics (CRMTs), Direct mail, Preferential Treatment, Interpersonal Communication, Tangible Rewards, Membership, Banking Industry, Customer loyalty

\section{Introduction}

According to Ahmed, Ismail, Sohail, Tabsh and Alias (2010), Malaysia first introduced credit cards in the mid-1970s. Since then, credit card issuers have been on an increasing trend. In 2009, there were 24 credit card issuers in Malaysia and by 2018; a total of 27 credit cards issuers are available. Within this number, 25 of them are banks while 2 of them are non-banks (Bank Negara Malaysia, 2018). The increasing number of credit cards issuers has encouraged a greater number of applicants and also competition among issuers. Banks are very much attracted to the credit card business as it is one of the most profitable services even if it is highly competitive (Sheng and Wah, 2011). Table 1 on the next page shows the number of credit card issuers in Malaysia by 2018.

In the late 2000's, the total number of credit card users in Malaysia has increased by 9.25 percent. However, by 2012, Bank Negara Malaysia (BNM) recorded that the number of applicants had reduce by 25.39 percent. The decreased number of credit card users since 2010 occurred when BNM imposed tax to the credit card requirement in order to reduce the number of applicants (The

\footnotetext{
${ }^{1}$ UITM MALAYSIA

${ }^{2}$ Universiti Teknologi MARA, Kedah,Malaysia

${ }^{3}$ Durham University, United Kingdom
} 
Kamarulzaman, M.H., Abidin,N.F.Z., Dahari, S.N.S (2018). The effect of customer relationship tactics toward customer loyalty in banking industry. International Journal of Social Sciences and Education Research, 4(2), 381-392.

EDGE Malaysia, 2009). The numbers of credit card users became even gloom when Deputy Finance Minister Datuk Lee Chee Leong stated that the numbers of credit cards user are only 3.6 million as at the end of June 2017 (The Sun Daily, 2017). This fluctuating and unstable trend has affected banks since credit card is one of the profit contributors for their business. Therefore, in order to retain the remaining credit card users, banks need a better approach to help them keep their loyal credit card customers. Table 2 below shows the number of credit card users in Malaysia from year 2007 to 2016 .

Table 1. Credit card issuers in Malaysia by 2018

\begin{tabular}{ll}
\hline \multicolumn{1}{c}{ Banks } & \multicolumn{1}{c}{ Non-Banks } \\
\hline 1. Affin Bank Berhad & 1. AEON Credit Service (M) Berhad \\
2. Affin Islamic Bank Berhad & 2. Synergy Cards Sdn. Bhd. \\
3. Alliance Bank Malaysia Berhad & \\
4. AmBank (M) Berhad & \\
5. AmIslamic Bank Berhad & \\
6. Bank of China (M) Berhad & \\
7. Bank Islam Malaysia Berhad & \\
8. Bank Kerjasama Rakyat Malaysia Berhad & \\
9. Bank Simpanan Nasional & \\
10. CIMB Bank Berhad & \\
11. CIMB Islamic Bank Berhad & \\
12. Citibank Berhad & \\
13. Hong Leong Bank Berhad & \\
14. HSBC Amanah Malaysia Berhad & \\
15. HSBC Bank Malaysia Berhad & \\
16. Industrial and Commercial Bank of China & \\
17. Malaysia) Berhad & \\
18. Maybank Islamic Berhad & \\
19. OCBC Bank (Malaysia) Berhad & \\
20. Public Bank Berhad & \\
21. Public Islamic Bank Berhad & \\
22. RHB Bank Berhad & \\
23. RHB Islamic Bank Berhad & \\
24. Standard Chartered Bank Malaysia Berhad & \\
25. United Overseas Bank (Malaysia) Berhad &
\end{tabular}

Source: Bank Negara Malaysia (2018)

Table 2. Total number of credit card users in Malaysia from year 2007 to 2016

\begin{tabular}{cc}
\hline Year & Total ('000) \\
\hline $\mathbf{2 0 0 7}$ & $5,566.9$ \\
\hline $\mathbf{2 0 0 8}$ & $5,738.6$ \\
\hline $\mathbf{2 0 0 9}$ & $4,829.2$ \\
\hline $\mathbf{2 0 1 0}$ & $2,364.7$ \\
\hline $\mathbf{2 0 1 1}$ & $2,498.0$ \\
\hline $\mathbf{2 0 1 2}$ & $2,617.4$ \\
\hline $\mathbf{2 0 1 3}$ & $2,814.9$ \\
\hline $\mathbf{2 0 1 4}$ & $2,782.0$ \\
\hline $\mathbf{2 0 1 5}$ & $3,827.1$ \\
\hline $\mathbf{2 0 1 6}$ & $\mathbf{3 . 6}$ million \\
\hline
\end{tabular}

Source: Bank Negara Malaysia (2018) 
Kamarulzaman, M.H., Abidin,N.F.Z., Dahari, S.N.S (2018). The effect of customer relationship tactics toward customer loyalty in banking industry. International Journal of Social Sciences and Education Research, 4(2), 381-392.

The rising of local and foreign banks gives the stiff competition to the banking institutions in term of attracting and retaining loyal customers. Today all banks are trying to gain a greater share of the market and the market leader in their own hands (Taleghani, Chirani, Mirrashed, 2011). The Global Consumer Banking Survey (GCBS, 2012) reported that worldwide, the proportion of customers planning to change banks has grown by $70 \%$ since 2011 . Globally, multi-banking is increasing as customers search more actively for the best rates and products including credit card services. Banks face a potential threat from new entrants offering better rates, more personalized service, stronger technology or more attractive rewards.

In addition, banks are looking for ways and information to reflect on their needs and interests and this information will reduce marketing costs and increase profitability (Kotler, 2003). Cost of acquiring or attracting a new consumer is estimated to be five times the cost of maintaining a consumer. It is therefore vital to maintain customers' loyalty and to attract more business. Therefore, bank should seek different management strategies to improve their customers' loyalty (Ehigie, 2006). One of the keys to retain existing consumers especially the credit card users is through proper practices of Customer Relationship Marketing Tactics (CRMTs).

The stiff competition between financial institutions and the changing trends of consumer's banking behaviour has posed greater challenge for the banking to retain loyal customers. The loyal customers that contribute profit to the banking institutions are precious and this will help the bank to keep and lower their cost rather than keep acquiring new customers. In order to retain loyal customers, Zhang and Feng (2009) stated that it is helpful for marketers to understand the usefulness of relationship marketing tactics from consumers' perspective. This is because Customer Relationship Marketing tactics are considered to be essential for building long-term relationship with customers in order to achieve mutual benefits for all parties. This study therefore is conducted to examine the influence of CRMTs toward credit card user's loyalty from the Malaysia context.

\section{Problem statement}

Customer is the key success for every business and the same is true for banking industry. In this study, researchers focus on credit card users because a credit card is one of the most profitable services for banking industry even though it is competitive (Sheng and Wah, 2011). Based on the fluctuation and unstable trend from year 2007 until 2016, the total credit card users were unstable decreasing from about 5.5 million users in 2007 to only about 2.3 million users in 2010. The number of credit card users start to increase in a year 2011 until year 2014 which is 2.7 million users and was recorded as at end of 2016, there are 3.6 million of credit card users in Malaysia. This trend had become a major concern for the card issuers because the market view as insecure because the users can be missing from the market as they want and they tend to become less loyal to one specific credit card issuer. This has been supported by the findings from the GCBS (2012) reported that, customers are becoming less loyal to their main bank, and they are increasing the number of banks they use.

By realizing this fact, credit card issuers had to strategize and implement many tactics in order to keep their credit card users to use their credit card services continuously. In addition, as claimed by Bagherzad, Chavosh and Hosseinikhah (2011), service providers are trying to use more tactics to encourage customers to become loyal customers. Credit card issuers such as Malayan Banking 
Kamarulzaman, M.H., Abidin,N.F.Z., Dahari, S.N.S (2018). The effect of customer relationship tactics toward customer loyalty in banking industry. International Journal of Social Sciences and Education Research, 4(2), 381-392.

Berhad(MBB) and CIMB Group Holding Berhad (CIMB) have used CRMTs as their tools in order to retain the credit card users. Furthermore, as cited by Keshvari and Zare (2012), there is lack of scientific study that focus on the effects of CRMTs in banking sector. This ground has made a strong reason why this study should be conducted. Furthermore, previous studies were carried out in other countries and not yet in Malaysia. Therefore, these scenarios create a need for researchers to add more knowledge in this area by examining the effects of CRMTs on credit card users' loyalty.

\section{Literature review}

According to Keshvari and Zare (2012), relationship marketing refers to a wide range of relationship marketing strategies that have developed over the past few decades in product as well as service markets and in consumer as well as in business to business sectors. The relationship marketing strategies involves several tactics such as service quality, price perception, value offers, brand image, communication, personalization, power and cooperation. In this study, Keshvari and Zare (2012) concluded that these eight CRMTs have meaningful relationship between customer trust, satisfaction, commitment and conflict management in banking industry. It implies that in banking industry, in any level the confidence building is growing, the customer's loyalty is increasing in the same level. Tseng (2007) had tested five CRMTs which are tangible rewards, Interpersonal communication, preferential treatment, membership and also direct mail. Researcher found that, preferential treatment and membership are significant for banking industry. Meanwhile, another three CRMTs which are direct mail, interpersonal communication and tangible reward are not significant for banking industry. Doaei, Rezaei and Khajei (2011) had used the same model as Tseng (2007) however; researchers tested four tactics out of five that exclude the membership. Researchers covered that, all the CRMTs were significant in generating of customer loyalty except preferential treatment. Researchers have ranked the CRMTs from most significant to the least significant which are direct mail, tangible reward, and interpersonal communication and lastly are preferential treatment.

Another study by Zhang and Feng (2009) have examined four CRMTs in the service industry which are service quality, price perception, value offered and brand image and all of four CRMTs are positively related to relationship qualities which are including satisfaction and trust. However among the tactics, value offers shows the lowest relationship with customer's trust and satisfaction. Concluded that, brand image tactics was directly leaded to customer loyalty regardless of the influence of relationship quality consist of satisfaction and trust. In addition, a study by KoiAkrofi, Welbeck and Koi-Akrofi (2012) adopted the viewpoints of Peng and Wang (2006) recommended that CRMTs in service industry consist of service quality, price perception, value offers and brand image. In this study, researchers declared that all the four CRMTs are significantly and positively correlated with the customer loyalty. Previous empirical study by Nakhleh (2012) also examined the same CRMTs which are service quality, price perception, value offers and brand image. Researchers found that, CRMTs have positive effect on customer loyalty though some of tactics which are value offers revealed the low relationship with customer loyalty. Therefore, by considering the past studies by Tseng (2007) and Doaei, Rezaei and Kajei (2011), this study adapts five CRMTs which are direct mail, preferential treatment, interpersonal communication, tangible rewards and membership. All the CRMTs will be further briefing below. 
Kamarulzaman, M.H., Abidin,N.F.Z., Dahari, S.N.S (2018). The effect of customer relationship tactics toward customer loyalty in banking industry. International Journal of Social Sciences and Education Research, 4(2), 381-392.

\section{Past studies on CRMTs and customer loyalty}

There are few studies have claimed the relationship between Customer Relationship Marketing tactics and customer loyalty. Table 3 below shows the past studies of CRMTs and customer loyalty.

Table 3. Past studies of CRMTs and customer loyalty

\begin{tabular}{|c|c|c|}
\hline Past studies & Purpose and findings & Key contribution \\
\hline $\begin{array}{l}\text { Koi-Akrofi, } \\
\text { Welbeck and } \\
\text { Koi-Akrofi (2012 }\end{array}$ & $\begin{array}{l}\text { Purpose : } \\
\text { To examine the contribution of CRMTs on customer loyalty in } \\
\text { the Ghanaian Mobile industry. } \\
\text { Findings: } \\
\text { 1. Positive relationship between service quality and customer } \\
\text { loyalty } \\
\text { 2. Positive relationship between price perception and cus- } \\
\text { tomer loyalty will make customer happy and stay con- } \\
\text { nected with the mobile operators } \\
\text { 3. Value offered found to be positively related to customer } \\
\text { loyalty suggests that the promotional offers by service pro- } \\
\text { vides are worth the money and people wish to always par- } \\
\text { ticipate in the promos offered. } \\
\text { 4. Increase in brand image may lead to increase in customer } \\
\text { loyalty and vice versa }\end{array}$ & $\begin{array}{l}\text { CRMTs' Tactics: } \\
\text { - Service quality } \\
\text { - Price perception } \\
\text { - Value offers } \\
\text { - Brand image }\end{array}$ \\
\hline $\begin{array}{l}\text { Horri, Shirsavar } \\
\text { and Mohaved } \\
\text { (2013) }\end{array}$ & $\begin{array}{l}\text { Purpose : } \\
\text { Provide a model and test the impact of relationship marketing } \\
\text { tactics on customer loyalty } \\
\text { Findings: } \\
\text { 1. CRMTs has a significant relationship with the quality of } \\
\text { the relationship between company and customer. } \\
\text { 2. Significant relationship between trust and relationship satis- } \\
\text { faction of the factors quality relationship and increase cus- } \\
\text { tomer is a significant relationship. } \\
\text { 3. Positive effect on relationship marketing tactics to increase } \\
\text { customer loyalty to the company. }\end{array}$ & $\begin{array}{l}\text { CRMTs' Tactics: } \\
\text { - } \quad \text { Direct correspond } \\
\text { - } \quad \text { Personal communication } \\
\text { - } \text { Tangible reward } \\
\text { Mediating: } \\
\text { - Trust } \\
\text { - } \quad \text { Relationship satisfaction }\end{array}$ \\
\hline $\begin{array}{l}\text { Keshvari and } \\
\text { Zare (2012) }\end{array}$ & $\begin{array}{l}\text { Purpose : } \\
\text { To study the marketing strategy of product, price, and service } \\
\text { quality, perception, values offers and upon promotion will ef- } \\
\text { fect on customer satisfaction and trust, which is turn increase } \\
\text { customer loyalty by focusing on Iranian banking system. } \\
\text { Findings: } \\
\text { Eight relationship marketing tactics that have meaningful rela- } \\
\text { tionship between customer trust, satisfaction, commitment and } \\
\text { conflict management } \\
\text { All the relationship marketing tactics } \\
\text { have directly impact on relationship quality elements }\end{array}$ & 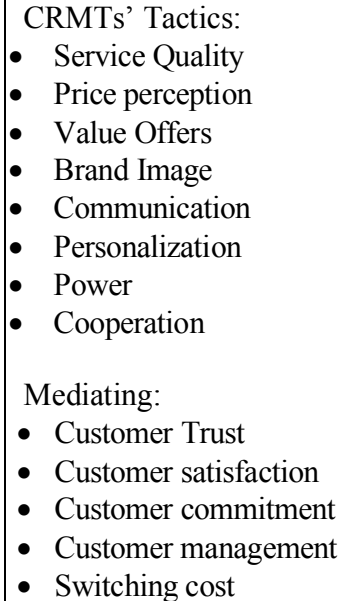 \\
\hline
\end{tabular}


Kamarulzaman, M.H., Abidin,N.F.Z., Dahari, S.N.S (2018). The effect of customer relationship tactics toward customer loyalty in banking industry. International Journal of Social Sciences and Education Research, 4(2), 381-392.

\begin{tabular}{|c|c|c|}
\hline $\begin{array}{l}\text { Aali, Nasab, } \\
\text { Fazeliyan and } \\
\text { Kheirollahi } \\
(2012) \text {, }\end{array}$ & $\begin{array}{l}\text { Purpose: } \\
\text { To evaluate the impact of relationship underpinnings on rela- } \\
\text { tionship quality } \\
\text { Findings: } \\
\text { 1. Positive relationship in product quality, product price, brand } \\
\text { image and value offers with customer satisfaction } \\
\text { 2. Positive relationship between customer satisfaction and cus- } \\
\text { tomer loyalty } \\
\text { 3. Positive relationship between quality of relation and cus- } \\
\text { tomer loyalty }\end{array}$ & 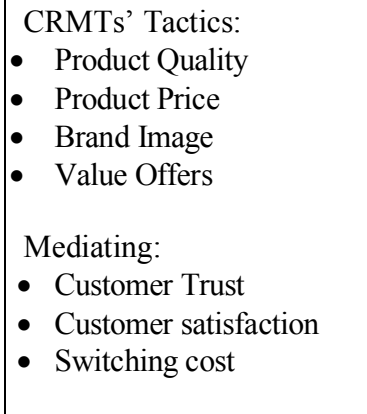 \\
\hline $\begin{array}{l}\text { Zhang and Feng } \\
\text { (2009) }\end{array}$ & $\begin{array}{l}\text { Purpose: } \\
\text { To investigate the impact of CRMTs on customer loyalty } \\
\text { within Swedish mobile telecommunication sector } \\
\text { Findings: } \\
\text { 1. Positive relationship in service quality, price perception, } \\
\text { brand image and value offers with customer satisfaction and } \\
\text { trust } \\
\text { 2. Positive relationships between satisfaction and customer } \\
\text { loyalty as well as trust } \\
\text { 3. The relationship between switching cost and customer loy- } \\
\text { alty is less significant }\end{array}$ & $\begin{array}{l}\text { CRMTs' Tactics: } \\
\text { - } \quad \text { Service Quality } \\
\text { - } \quad \text { Price Perception } \\
\text { - } \text { Brand Image } \\
\text { Medue Offers } \\
\text { Mediating: } \\
\text { - Customer Trust } \\
\text { - Customer satisfaction } \\
\text { - Switching cost }\end{array}$ \\
\hline Tseng (2007) & $\begin{array}{l}\text { Purpose: } \\
\text { Explore the effects of CRMTs on enhancing relationship quality } \\
\text { in three services industry namely banking, airlines and travel } \\
\text { agencies } \\
\text { Findings: } \\
\text { 1. Significance relationship in membership and preferential } \\
\text { treatment in banking and airlines industries } \\
\text { 2. Significant relationship between tangible rewards and cus- } \\
\text { tomer loyalty in travel agencies industry } \\
\text { 3. Tangible rewards, preferential treatment and membership } \\
\text { have influenced customers' relationship quality and loy- } \\
\text { alty. }\end{array}$ & $\begin{array}{l}\text { CRMTs' Tactics: } \\
\text { - Direct Mail } \\
\text { - Preferential Treatment } \\
\text { - Interpersonal Communi- } \\
\text { - cation } \\
\text { - Tangible Rewards } \\
\text { - Membership } \\
\\
\text { Relationship Quality }\end{array}$ \\
\hline
\end{tabular}

\section{Theoretical framework}

In order to examine the influence of CRMTs on the Credit card user's loyalty, Researchers have developed the above theoretical framework (Figure 1). The instrument used was adapted from Tseng (2007) and Doaei, Rezaei and Kajei (2011) earlier related studies.

Figure 1. Theoretical Framework of the study

\section{CRMTs}

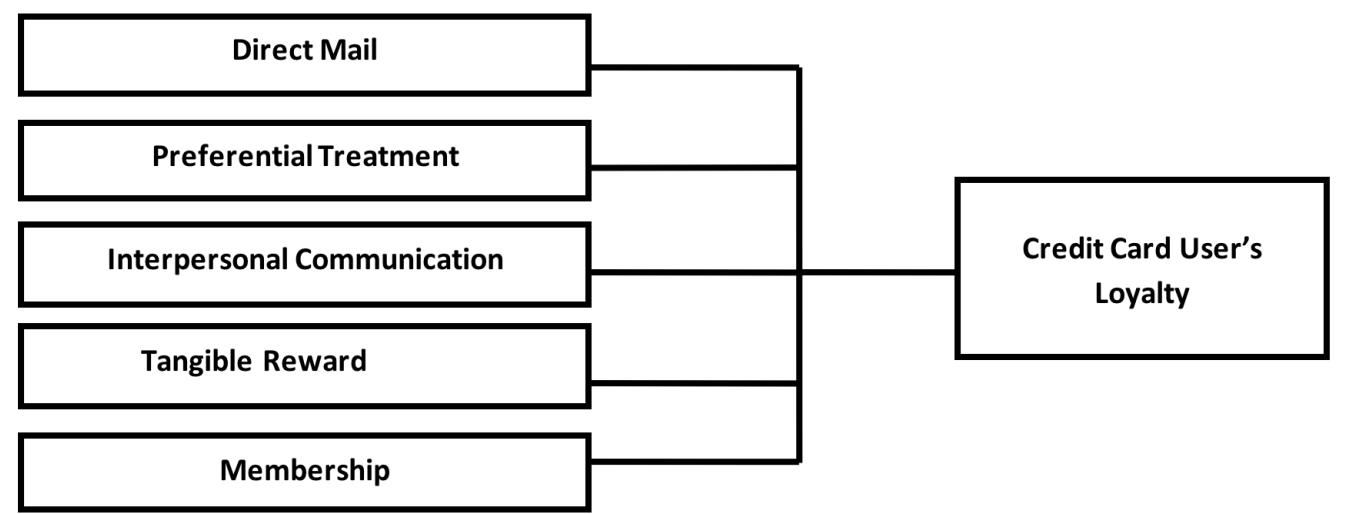


Kamarulzaman, M.H., Abidin,N.F.Z., Dahari, S.N.S (2018). The effect of customer relationship tactics toward customer loyalty in banking industry. International Journal of Social Sciences and Education Research, 4(2), 381-392.

\section{Methodology}

\subsection{Sample and data collection method}

The sampling unit for this study is Credit card users of MBB and CIMB. Researchers distributed 350 questionnaires to respondents at shopping malls and offices around Shah Alam and snowball sampling that was allocated via researcher's acquaintances nearby Shah Alam. Researchers used the snowball sampling that allowed one respondent to suggest for another respondent in order to answer the questionnaire. The questionnaire has been distributed until it reaches the target sample size of 100 respondents for each bank.

\subsection{Sampling technique}

For this study, two non-probability sampling used which were snowball and convenience sampling. As the population for this research were the credit card users of MBB and CIMB. The distributions of questionnaire were allocated at shopping malls, banking branches and offices around Shah Alam. 500 questionnaires were physically distributed and targeted 100 usable questionnaires for each bank combination from snowball and convenience distribution will be selected for findings and analysis within 14 days.

\section{Finding and discussion}

\subsection{Demographics profile}

From the data obtained, majority of the credit card users was between aged 31 to 40 years old with the percentage of 34.0 and 32.0 percent accordingly. The possible reason was maybe due to the largest financial commitments among the older generation (Tan, Yen, Loke, 2011). Whereas, female credit card users were 50.0 percent for MBB and 54.0 percent for CIMB. The female was the majority of respondents of this research with the total percentage of 52.0 percent, slightly higher than male. Female was the most reachable target respondent compared to male and possible that they preferred to use a credit card in daily transactions or during emergency time.

The highest percentage of educational level was bachelor degrees with a 50.0 percent of MBB and 55.0 percent of CIMB's user have the education level of bachelor degrees. Most of credit card user is bachelor degree holder and were in executive level with a salary between RM 3001- RM 5000. This fact explained that most of the users have Classic credit card because it is the most eligible category for customer with a minimum annual income of RM15, 000.

\subsection{Reliability analysis}

The Cronbach's alpha coefficient value for all variables in the study revealed a range of coefficient value from 0.77 to 0.91 accordingly. The dependent variable of credit card user's loyalty had very good reliability coefficient of 0.876 . The independent variables of direct mail, preferential treatment, interpersonal communication, tangible reward and membership had 0.844, 0.775, $0.852,0.917$ and 0.851 respectively; this indicates all variables have range between good to excellent reliability.

\subsection{Descriptive statistics}

Descriptive analysis has tested the mean of overall CRMTs practiced by both banks. According to the test, both banks have a mean of 3.51 and 3.57 respectively. Credit card issuers have ranked both banks CRMTs practiced by MBB and CIMB as a neutral which means not so good 
Kamarulzaman, M.H., Abidin,N.F.Z., Dahari, S.N.S (2018). The effect of customer relationship tactics toward customer loyalty in banking industry. International Journal of Social Sciences and Education Research, 4(2), 381-392.

and not so bad also. In term of loyalty, researchers found the overall mean of 3.79 for MBB and 3.78 for CIMB explained that, credit card users felt neutral in term of their loyalty toward both banks.

\subsection{Pearson correlation}

Based on the Pearson correlation, researchers have ranked the CRMTs for MBB.

Table 4. Pearson correlation test for MBB

\begin{tabular}{clcll}
\hline Rank & DV and IV & $\begin{array}{c}\text { Pearson } \\
\text { Correlation }\end{array}$ & Level & Significant \\
\hline $\mathbf{3}$ & $\begin{array}{l}\text { Mean Credit card holder's loyalty } \\
\text { and Direct Mail }\end{array}$ & 0.435 & $\begin{array}{l}\text { Moderate correlation, sub- } \\
\text { stantial relationship }\end{array}$ & Yes / 0.000 \\
\hline $\mathbf{5}$ & $\begin{array}{l}\text { Mean Credit card holder's loyalty } \\
\text { and Preferential treatment }\end{array}$ & 0.348 & $\begin{array}{l}\text { Low correlation, definite } \\
\text { but small relationship }\end{array}$ & Yes / 0.000 \\
\hline $\mathbf{4}$ & $\begin{array}{l}\text { Mean Credit card holder's loyalty } \\
\text { and Interpersonal communication }\end{array}$ & 0.432 & $\begin{array}{l}\text { Moderate correlation, sub- } \\
\text { stantial relationship }\end{array}$ & Yes/ 0.000 \\
\hline $\mathbf{2}$ & $\begin{array}{l}\text { Mean Credit card holder's loyalty } \\
\text { and Tangible rewards }\end{array}$ & 0.523 & $\begin{array}{l}\text { Moderate correlation, sub- } \\
\text { stantial relationship }\end{array}$ & Yes / 0.000 \\
\hline $\mathbf{1}$ & $\begin{array}{l}\text { Mean Credit card holder's loyalty } \\
\text { and Membership }\end{array}$ & 0.774 & $\begin{array}{l}\text { High correlation, marked } \\
\text { relationship }\end{array}$ & Yes/ 0.000 \\
\hline & $\begin{array}{l}\text { Mean Credit card holder's loyalty } \\
\text { and CRMTs }\end{array}$ & 0.671 & $\begin{array}{l}\text { Moderate correlation, sub- } \\
\text { stantial relationship }\end{array}$ & Yes/ 0.000 \\
\hline
\end{tabular}

Table 5. Pearson correlation test for CIMB

\begin{tabular}{cllll}
\hline Rank & DV and IV & $\begin{array}{l}\text { Pearson } \\
\text { Correlation }\end{array}$ & Level & Significant \\
\hline $\mathbf{2}$ & $\begin{array}{l}\text { Mean Credit card holder's loy- } \\
\text { alty and Direct Mail }\end{array}$ & 0.560 & $\begin{array}{l}\text { Moderate correlation, sub- } \\
\text { stantial relationship }\end{array}$ & Yes / 0.000 \\
\hline $\mathbf{5}$ & $\begin{array}{l}\text { Mean Credit card holder's loyalty } \\
\text { and Preferential treatment }\end{array}$ & 0.104 & $\begin{array}{l}\text { Slight, almost insignifi- } \\
\text { cant relationship }\end{array}$ & No / 0.151 \\
\hline $\mathbf{3}$ & $\begin{array}{l}\text { Mean Credit card holder's loyalty } \\
\text { and Interpersonal communication }\end{array}$ & 0.468 & $\begin{array}{l}\text { Moderate correlation, sub- } \\
\text { stantial relationship }\end{array}$ & Yes/ 0.000 \\
\hline $\mathbf{4}$ & $\begin{array}{l}\text { Mean Credit card holder's loyalty } \\
\text { and Tangible rewards }\end{array}$ & 0.441 & $\begin{array}{l}\text { Moderate correlation, sub- } \\
\text { stantial relationship }\end{array}$ & Yes / 0.000 \\
\hline $\mathbf{1}$ & $\begin{array}{l}\text { Mean Credit card holder's loyalty } \\
\text { and Membership }\end{array}$ & 0.694 & $\begin{array}{l}\text { Moderate correlation, sub- } \\
\text { stantial relationship }\end{array}$ & Yes/0.000 \\
\hline & $\begin{array}{l}\text { Mean Credit card holder's loyalty } \\
\text { and CRMTs }\end{array}$ & 0.605 & $\begin{array}{l}\text { Moderate correlation, sub- } \\
\text { stantial relationship }\end{array}$ & Yes/ 0.000 \\
\hline
\end{tabular}

Researchers determine the relationship between each independent variable with the dependent variable which is credit card user's loyalty for MBB and CIMB. Every independent variable has a different degree of relationship and for $\mathrm{MBB}$, researchers have ranked the highest correlation to low correlation accordingly start from membership, tangible reward, direct mail, interpersonal communication and lastly preferential treatment. For CIMB, the rank was membership, direct mail, interpersonal communication, tangible reward and lastly preferential treatment. 
Kamarulzaman, M.H., Abidin,N.F.Z., Dahari, S.N.S (2018). The effect of customer relationship tactics toward customer loyalty in banking industry. International Journal of Social Sciences and Education Research, 4(2), 381-392.

\subsection{Multiple regressions}

\subsubsection{Multiple regressions for $M B B$}

Only membership has the highest contribution or most influence independent variables toward the credit card user's loyalty of MBB and another four independent variables (direct mail, preferential treatment, interpersonal communication, and tangible reward) were insignificant.

Table 6. Regression test for MBB

\begin{tabular}{llll}
\hline Independent variable & Beta value & Significant level & Contribution \\
\hline Membership & 0.670 & 0.00 & High contribution/significant \\
\hline Direct Mail & 0.018 & 0.840 & Weak contribution/insignificant \\
\hline Preferential treatment & 0.094 & 0.183 & Weak contribution/insignificant \\
\hline Interpersonal communication & 0.050 & 0.558 & Weak contribution/insignificant \\
\hline Tangible reward & 0.095 & 0.275 & Weak contribution/insignificant \\
\hline
\end{tabular}

\subsubsection{Multiple regressions for CIMB}

There were two CRMTs that significant for CIMB which membership and direct mail are, whereas another three CRMTs which are preferential treatment, interpersonal communication, and tangible reward were insignificant.

Table 7. Regression test for CIMB

\begin{tabular}{llll}
\hline Independent variable & Beta value & Significant level & Contribution \\
\hline Membership & 0.622 & 0.00 & High contribution/significant \\
\hline Direct Mail & 0.364 & 0.00 & Low contribution/significant \\
\hline Preferential treatment & 0.136 & 0.071 & Weak contribution/insignificant \\
\hline Interpersonal communication & 0.124 & 0.259 & Weak contribution/insignificant \\
\hline Tangible reward & 0.018 & 0.855 & Weak contribution/insignificant \\
\hline
\end{tabular}

\section{Conclusion and Recommendation}

\subsection{Conclusion}

Based on descriptive statistic result, there are certain areas that need to be improved by the management of MBB and CIMB due to lower rating. The area that needs to be improved by the MBB and CIMB were both banks has less effort of utilized social media medium in order to communicate with credit card user. Besides, user cannot value both banks effort in term of personalized their treatment to them, it's probably the bank representatives were unable to performing preferential treatment or unaware of applying this. Next, they were not so impressed or valued the efforts by service representatives. They also perceived the tangible reward of MBB and CIMB at scale level of 3 , a lot of improvements can be taken especially on improving the offers of money saving to them as it has the lowest mean which are 3.87 and 3.84 respectively. Besides, most of them were not really willing to travel extra mile in order to seek services from them. Overall, the practice of CRMTs shows the mean of 3.51 and 3.57 for MBB and CIMB and this indicates that the CRMTs implemented by both banks considered as an "average or moderate" by user. Moreover, they felt neutral relationship and loyalty toward both banks.

The Pearson coefficient analysis for MBB found that all the independent variables have the significant relationship with credit card user's loyalty. Researchers have ranked the CRMTs that 
Kamarulzaman, M.H., Abidin,N.F.Z., Dahari, S.N.S (2018). The effect of customer relationship tactics toward customer loyalty in banking industry. International Journal of Social Sciences and Education Research, 4(2), 381-392.

have the highest relationship to the lowest relationship for MBB which membership, tangible reward, direct mail, interpersonal communication and preferential treatment are. Meanwhile for CIMB are membership, direct mail, interpersonal communication, tangible reward and preferential treatment. Both results were not similar with previous study by Doaei, Rezaei and Khajei (2011), researchers used and tested four tactics out of five that exclude the membership and they have ranked the CRMTs from most significant to the least significant which were Direct mail $>$ tangible reward $>$ and interpersonal communication $>$ preferential treatment.

However, for look into deeper view, researchers have used multiple regression tests. For MBB, there was only membership that most significant. Meanwhile, another four independent variables which were direct mail, tangible reward, interpersonal communication and preferential treatment were insignificant for MBB. Meanwhile for CIMB, researchers claimed that there were two CRMTs that have significant contribution in order to generate the credit card user's loyalty for CIMB which are membership and direct mail. Whereas, researchers declared another three tactics was insignificant for CIMB.

The most significant CRMTs for both banks were membership with Beta value of 0.670 for MBB and 0.622 for CIMB. This has been supported by a study from Waarden (2008) and Tseng (2007) that positive relationship of cardholder to be more loyal as compared to the non-members. The study indicates that membership as the approach of company to keep customer loyal and reduces the switching intention. The second IV that contributes to the user's loyalty for CIMB was direct mail and supported by the previous study of Verhoef (2002) and Doaei, Rezaei and Khajei (2011). Conversely for MBB, the direct mail was insignificant in order to generate the user's loyalty and this finding similar with a study by Tseng (2007). CRMTs that were insignificant for both banks include tangible reward, supported by Tseng (2007) and Horri, Shirsavar, and Mohaved (2013). However, this finding was opposed with the study by Doaei et al., (2011). Next is interpersonal communication and this is also supported by Tseng (2007) and was opposed by Doaei et al., (2011) and Lo, Lycnh and Staelin (2007). Last is preferential treatment and this finding was supported by Doaei et al., (2011) and contradicted with a study from Tseng (2007).

\subsection{Recommendation}

The specific recommendations can be derived in Table 8. as below:

Table 8. Specific recommendations for MBB and CIMB

\begin{tabular}{|c|c|}
\hline Recommendation for MBB & Recommendation for CIMB \\
\hline $\begin{array}{l}\text { 1. Create effective and creative customer loyalty } \\
\text { programs for encouraging the involvement of } \\
\text { members (i.e. fundraising or auctions that specif- } \\
\text { ically exhibit for credit card user) } \\
\text { 2. Create a special credit card centre at branches } \\
\text { and any places that reachable such as complex, } \\
\text { Kuala Lumpur Central and airport) }\end{array}$ & $\begin{array}{l}\text { Create effective and creative customer loyalty pro- } \\
\text { grams for encouraging the involvement of members } \\
\text { (i.e. fundraising or auctions that specifically exhibit } \\
\text { for credit card user) } \\
2 \text {. Create a special credit card centre at branches and } \\
\text { any places that reachable such as complex, Kuala } \\
\text { Lumpur Central and airport) }\end{array}$ \\
\hline $\begin{array}{l}\text { MBB can offer more benefits of money saving to } \\
\text { the credit card users such as cash rebates and dis- } \\
\text { count. }\end{array}$ & $\begin{array}{l}\text { Utilized social media medium such as Facebook, } \\
\text { Twitter and forums to deliver information and com- } \\
\text { municate to credit card users. (create special forums } \\
\text { for credit card holder) }\end{array}$ \\
\hline
\end{tabular}


Kamarulzaman, M.H., Abidin,N.F.Z., Dahari, S.N.S (2018). The effect of customer relationship tactics toward customer loyalty in banking industry. International Journal of Social Sciences and Education Research, 4(2), 381-392.

\section{References}

Aali, M. B., Nasab, S. D. H., Fazeliyan, S. M. And Kheirollahi, H. (2012). Relationship Marketing and Customer Loyalty (case study: Hormozghan Cement Co., Bandar Khamir, L. R. Iran), Journal of Basic Applied Science and Research, 2(12)11970-11977.

Ahmed, Z. U., Ismail, I., Sohail, M. S., Tabsh, I. and Alias, H. (2010). Malaysian consumers' credit card usage behavior, Asia Pacific Journal of Marketing and Logistics, 22(4).

Bagherzad, A.,Chavosh, A and Hosseinikhah, S. (2011), "The influence of relationship marketing tactics on customer's loyalty in B2C relationship-the role of communication and personalization", European Journal of Economics, Finance and Administrative Sciences, Vol. 5(31), pp. 49-56.

Bank Negara Malaysia (2018). List of Issuers of Credit Cards, Charge Cards, E-money and Remittance Service Providers. Retrieved April 08, 2018, from http://www.bnm.gov.my/index.php?ch=ps\&pg=ps_regulatees\#Credit

Bank Negara Malaysia (2018). Number of Cards and Users of Payment Instruments, Retrieved April 8, 2018, from http://www.bnm.gov.my/payment/statistics/pdf/03_cards.pdf

Doaei, H., Rezaei, A., and Khajei, R. (2011). The impact of Relationship Marketing Tactics on Customer Loyalty: The Mediation Role of Relationship Quality. International Journal of Business Administration, 2(3), 83-93.

Ehigie, B. O. (2006). Correlates of customer loyalty to their bank: A case study in Nigeria, International Journal of Bank Marketing, 24 (7), 494-508.

Global Consumer Banking Survey, (2012). Retrieved on April 9, 2018 at http://www.ey.com/Publication/vwLUAssets/Global_Consumer_Banking_Survey_2012_The_customer_takes_control/\$FILE/Global_Consumer_Banking_Survey_2012.pdf

Horri, M. S., Shirsavar, H. R. A. And Mohaved, A. B. (2013). The Effect of Relationship Marketing Tactics on Customer Loyalty given the mediating role of quality relationship (case study: Shahab Gas Industries), Journal of Basic Applied Science and Research, 3(3) 414-419.

Keshvari, R. S. And Zare, T. (2012). The effect of customer relationship marketing tactics on banking customer loyalty, within Iranian banking industry, International conference on Education, Applied Sciences and Management.

Koi-Akrofi, G. Y., Welbeck, J. N. O. And Koi-Akrofi, J. (2012), relationship marketing tactics and customer loyalty - a case of mobile telecommunication industry in Ghana, Asian Journal of Business Management 5(1) 77-92.

Kotler, P. (2003). Marketing Insights from A to Z: 80 Concepts Every Manager Needs to Know, John Wiley \& Sons, Inc, Hoboken, New Jersey.

Lo, A., Lynch J.., Staelin, R., (2007), "How to attract customers by giving them the short end of the stick", Journal of Marketing Research, 44(1): 128- 141.

Nakhleh, H.M.A (2012). The relationship between customer relationship marketing tactics, relationship quality and customer's loyalty in mobile communication industry, 3(2), 538-547.

Peng, L.Y. and Wang,Q. (2006). Impact of Relationship Marketing Tactics(RMTs) on Switchers and Stayers in a competitive industry. Journal Marketing Management., 22, 25-29.

Sheng, L. K. and Wah, T. Y. (2011). A Comparative Study of Data Mining Techniques in Predicting Consumers' Credit Card Risk in Banks, African Journal of Business Management, 5 (20), 8307-8312.

Taleghani, M., Chirani, E. And Mirrashed, A. (2011), a conceptuality approach to relationship marketing and customers loyalty to banks, Journal of Basic and Applied Scientific Research, 1(11) 2022-2025.

Tan, A. K. G, Yen, S. T., and Loke, Y. J. (2011). Credit Card holders, Convenience users and revolvers: and ordinal treatment, Journal of Applied Economics, 14 (2), 225-255. 
Kamarulzaman, M.H., Abidin,N.F.Z., Dahari, S.N.S (2018). The effect of customer relationship tactics toward customer loyalty in banking industry. International Journal of Social Sciences and Education Research, 4(2), 381-392.

The EDGE Malaysia (2009), the MARC: New credit card tax unlikely to reduce consumer spending, Retrieved April 8, 2018, from http://www.theedgemalaysia.com/highlights/152571-marc-new-credit-cardtax-unlikely-to-reduce-consumer-spending.html

The Sun Daily (2017), 3.6m credit card holders in Malaysia as at June,Retrieved April 8, 2018 from http://www.thesundaily.my/news/2017/08/21/36m-credit-card-holders-malaysia-june

Tseng,Y.M.(2007). The Impactsof Relationships Marketing Tactics on Relationsip Quality in Service Industry. The business review, Cambridge, 7(2),310.

Verhoef. P. (2002). The Joint Effect of Relationship Perceptions, Loyalty Program and Direct Mailings on Customer Share Development, ERIM Report Series Research in Management, 27.

Waarden, L. M. (2008). The Influence of Loyalty Programme Membership on Customer Purchase Behaviour, European Journal of Marketing, 42 87-114.

Zhang, X. \& Feng, Y. (2009). The impact of customer relationship marketing tactics on customer loyalty. Master's Thesis, Halmstad University 